Original Article

\title{
A Study to assess the effectiveness of structured teaching programme on knowledge regarding the risk factors on occurrence of coronary artery disease among sedentary workers in selected urban area of Jaipur
}

\author{
Mr. Nemi Chand Jat (Ph.D. Scholar) ${ }^{1}$ \\ Prof. (Dr.) Yogesh Yadav \\ ${ }^{1}$ Principal, Rajasthan College of Nursing, Bagru Road Jaipur \\ ${ }^{2}$ Dean/Principal, Maharaj Vinayak Global University,Jaipur, Rajasthan \\ Corresponding Email : nemijat60@gmail.com
}

\begin{abstract}
:
Introduction : Cardiovascular disease is expected to cause 25 million deaths in the entire world in 2020 . The curbing of the mortality rate associated with this disease in developed countries that has taken place in recent decades is mainly due to the advances in treatment and early diagnosis. the developing societies have to face a hostile setting characterized by changes in lifestyle, basically aimed toward an increase in the consumption of foods with a high caloric density, a reduction of physical activity, and an increase in tobacco use.

Material and Method: The present study will be conducted in the Chomu Town at Jaipur District Rajasthan. present study conduct on 200 Sedentary workers were selected by purposive sampling technique ,non probability sampling approach, an evaluative approach with pre-experimental with one group pre-test and post-test design was considered A structured questionnaire was prepared to assess the knowledge of Sedentary Workers.

Result: In this study 41.7 percent respondents belonged to the age group of 18-28 years it was observed that 45 percent had Under Graduate that the 55 percent of the respondents were Computer Professional and $70 \%$ of respondents were Hindus The highest pre test knowledge score $36.3 \%$ was obtained in the aspect of symptoms \& diagnostic procedure of coronary artery disease the highest post test mean knowledge score $(97.1 \%)$ was found in the aspect of symptoms \& diagnostic procedure of coronary artery disease the overall pre-test mean knowledge score was found to be 26.3 percent and SD as $12.6 \%$ among the respondents. the overall post-test mean knowledge was found to be 86.8 percent and SD as $10.4 \%$ among the respondents.

Conclusion: Sedentary workers have moderate knowledge regarding the risk factors on occurrence of coronary artery disease. So the study recommends for STP conduct for the imparting knowledge to sedentary workers High knowledge can alter favorable attitude.
\end{abstract}

Key Words: Knowledge, coronary artery disease, sedentary workers, attitude.

\section{INTRODUCTION}

The WHO expert committee on prevention of Coronary Artery Disease identified a number of lifestyles and environmental factors as the underlying causes of CHD. These risk factors may be conceptualised as modifiable and non modifiable. Age, sex, smoking history of high blood pressure, diabetes, elevated plasma cholesterol /triglycerides, obesity, sedentary lifestyle, personality type and psychological stress are considered some of the major risk factors for CAD. Of the many known risk factors, age, sex and genetic pre-disposition cannot be altered.

\section{MATERIALAND METHODS}

A quasi-experimental approach was considered as appropriate one for present study. The main aim of this study was to find the effectiveness of structured teaching programme on knowledge regarding the risk factors on occurrence of coronary artery disease among sedentary workers by comparing pre and post knowledge score and To determine the association between mean pre test knowledge score and selected demographic variable such as age, education, religion, income, type of family, source of information and knowledge score regarding the risk factors on occurrence of coronary artery disease among sedentary workers. 
RESULTS

Section-I: Description of demographic characteristics.

Table 1 Distribution of Respondents by Age, Education and Occupation

\begin{tabular}{|c|c|c|c|}
\hline \multirow[t]{2}{*}{ Characteristics } & \multirow[t]{2}{*}{ category } & \multicolumn{2}{|c|}{ respondents } \\
\hline & & Number & Percent \\
\hline Age & $\begin{array}{l}18-28 \\
28-38 \\
38-45\end{array}$ & $\begin{array}{l}84 \\
50 \\
66\end{array}$ & $\begin{array}{l}41.7 \\
25.0 \\
33.3\end{array}$ \\
\hline $\begin{array}{l}\text { Educational } \\
\text { level }\end{array}$ & $\begin{array}{l}\text { Under graduate } \\
\text { Post graduate } \\
\text { No formal education }\end{array}$ & $\begin{array}{l}90 \\
34 \\
76\end{array}$ & $\begin{array}{l}45.0 \\
16.7 \\
38.3\end{array}$ \\
\hline Occupation status & $\begin{array}{l}\text { Computer } \\
\text { professionals } \\
\text { Clerk }\end{array}$ & $\begin{array}{l}90 \\
110\end{array}$ & $\begin{array}{l}45.0 \\
55.0\end{array}$ \\
\hline Total & & 200 & 100.0 \\
\hline
\end{tabular}

In this study 41.7 percent respondents belonged to the age group of 18-28 years followed by 33.3 percent respondents who belonged to the age group of $38-45$ years of age and remaining 25 percent were in the age group of 28-38 years.

Also in this study it was observed that 45 percent had Under Graduate followed by 38.3 percent with Other education and 16.7 percent had studied up to the Post Graduate.

Further, type of working indicates that 45 percent of the respondents were Computer Professional and remaining 55 percent of the respondents were Clerk

Section II: A rating scale will be used to assess the knowledge regarding the risk factors on occurrence of coronary artery disease among sedentary workers. This section consists of-

(A). Aspect wise distribution of scores during pretest and post-test.

(B). Association between pre-test and post-test knowledge scores.

Table No. 2 (A) Aspect wise Pre-test Mean Knowledge Score on Prevention of RTIs

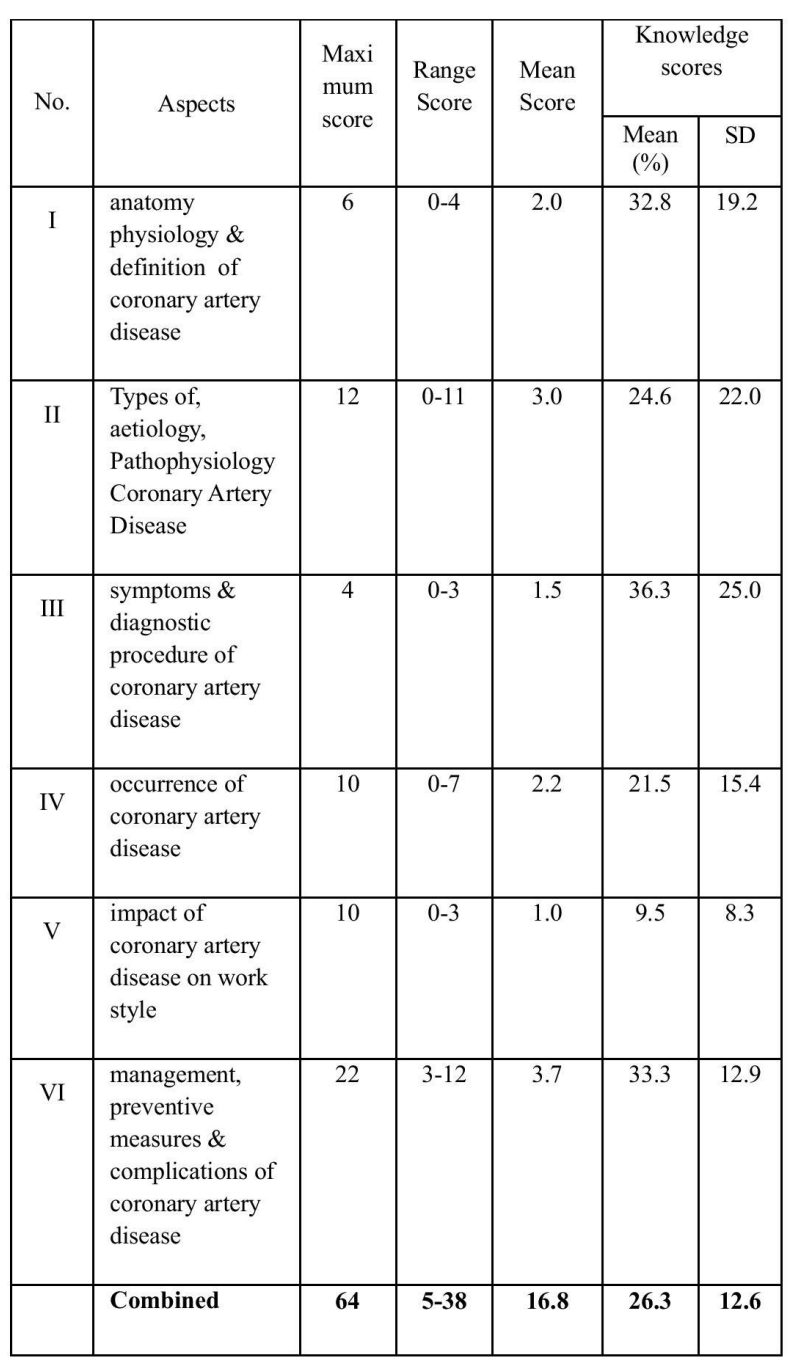

Aspect wise mean knowledge score regarding occurrence of coronary artery disease obtained by respondents-36.3\% was obtained in the aspect of symptoms \& diagnostic procedure of coronary artery disease, followed by $33.3 \%$ with regard to management, preventive measures $\&$ complications of coronary artery disease, $32.8 \%$ with regard to anatomy physiology \& definition of coronary artery disease, $24.6 \%$ with Types of, aetiology, Pathophysiology Coronary Artery Disease, $21.5 \%$ with occurrence of coronary artery disease and only $9.5 \%$ with regard to impact of coronary artery disease on work style. 
However, the overall pre-test mean knowledge score was found to be 26.3 percent and SD as $12.6 \%$ among the respondents.

Table No. 2 B Aspect wise Post-test Mean Knowledge Score on Prevention of RTIs $\mathbf{N}=\mathbf{2 0 0}$

\begin{tabular}{|c|c|c|c|c|c|c|}
\hline \multirow{2}{*}{ No. } & \multirow{2}{*}{ Aspects } & \multirow{2}{*}{$\begin{array}{l}\text { Maximum } \\
\text { score }\end{array}$} & \multirow{2}{*}{$\begin{array}{l}\text { Range } \\
\text { Score }\end{array}$} & \multirow{2}{*}{$\begin{array}{l}\text { Mean } \\
\text { Score }\end{array}$} & \multicolumn{2}{|c|}{$\begin{array}{l}\text { Knowledge } \\
\text { scores }\end{array}$} \\
\hline & & & & & $\begin{array}{c}\text { Mean } \\
(\%)\end{array}$ & SD \\
\hline I & $\begin{array}{l}\text { anatomy } \\
\text { physiology \& } \\
\text { definition of } \\
\text { coronary artery } \\
\text { disease }\end{array}$ & 6 & $4-6$ & 5.7 & 94.4 & 9.0 \\
\hline II & $\begin{array}{l}\text { Types of, } \\
\text { aetiology, } \\
\text { Pathophysiology } \\
\text { Coronary Artery } \\
\text { Disease }\end{array}$ & 12 & $3-12$ & 10.9 & 90.6 & 12.3 \\
\hline III & $\begin{array}{l}\text { symptoms \& } \\
\text { diagnostic } \\
\text { procedure of } \\
\text { coronary artery } \\
\text { disease }\end{array}$ & 4 & $1-4$ & 3.9 & 97.1 & 11.4 \\
\hline IV & $\begin{array}{l}\text { occurrence of } \\
\text { coronary artery } \\
\text { disease }\end{array}$ & 10 & $5-10$ & 8.1 & 81.0 & 15.4 \\
\hline V & $\begin{array}{l}\text { impact of coronary } \\
\text { artery disease on } \\
\text { work style }\end{array}$ & 10 & $2-10$ & 7.8 & 77.8 & 17.9 \\
\hline VI & $\begin{array}{l}\text { management, } \\
\text { preventive } \\
\text { measures \& } \\
\text { complications of } \\
\text { coronary artery } \\
\text { disease }\end{array}$ & 22 & $8-22$ & 19.3 & 87.7 & 9.8 \\
\hline & Combined & 64 & $47-64$ & 57.6 & 86.8 & 10.4 \\
\hline
\end{tabular}

The highest mean knowledge score (97.1\%) was found in the aspect of symptoms \& diagnostic procedure of coronary artery disease, followed by anatomy physiology \& definition of coronary artery disease (94.4\%), Types of, aetiology, Pathophysiology Coronary Artery Disease (90.6\%), management, preventive measures \& complications of Coronary Artery Disease $(87.7 \%)$, management, occurrence of coronary artery disease $(81 \%)$ and less mean knowledge score $(77.8 \%)$ found in the aspect of impact of coronary artery disease on work style. However, the overall post-test mean knowledge was found to be 86.8 percent and SD as $10.4 \%$ among the respondents

Table No. 2 C Association between pre-test and posttest knowledge scores

Mean Knowledge Scores of Pre-test and Post-tests on occurrence of coronary artery disease

$\mathrm{N}=200$

\begin{tabular}{|c|c|c|c|c|c|}
\hline \multirow{2}{*}{ Aspects } & \multirow{2}{*}{$\begin{array}{l}\text { Max. } \\
\text { Score }\end{array}$} & \multirow{2}{*}{$\begin{array}{l}\text { Mean } \\
\text { Score }\end{array}$} & \multicolumn{2}{|c|}{$\begin{array}{c}\text { Knowledge } \\
\text { scores }\end{array}$} & \multirow{2}{*}{$\begin{array}{l}\text { Paired } \\
t-\text { Value }\end{array}$} \\
\hline & & & $\begin{array}{c}\text { Mean } \\
(\%)\end{array}$ & SD & \\
\hline Pre-test & 64 & 16.8 & 26.3 & 12.6 & \multirow{2}{*}{$44.07 *$} \\
\hline Post-test & 64 & 57.6 & 86.8 & 10.4 & \\
\hline Enhancement & 64 & 38.3 & 60.6 & 11.0 & \\
\hline
\end{tabular}

* Significant at 5\% Level

Despites the association of age and knowledge of respondents on occurrence of coronary artery disease (scores of pre-test and post-test) which reveals the post-test mean scores found greater than pre-test scores in all the age groups under study.

However, the enhancement was higher in the age group of $28-38$ years $(63.9 \%)$ followed by $38-45$ years of age with $(61.1 \%)$ and in the age group of $18-28$ years was 58.6 percent. It was interesting to note that the lower the age of the respondents better was the knowledge level.

\section{DISCUSSION}

Coronary artery disease is the single largest killer of both men and women worldwide. Coronary artery disease and also called as ischemic heart disease. it has been defined as "impairment of heart function due 
to inadequate blood flow to the heart compared to its needs, caused by obstructive changes in the coronary circulation to the heart"

Coronary artery disease occurs due to damage to the main blood vessels that supply oxygen Deposition of cholesterol and formation of plaque (atherosclerosis) is the main reason that causes damage to these arteries. it is, when one or more of the coronary arteries become narrowed or totally blocked by a gradual build up of fat (cholesterol) within the artery wall, which reduces blood flow to the heart muscle. As a result, the heart muscle does not get the oxygen rich blood that it needs and it begins to die.

\section{CONCLUSION}

In this study 41.7 percent respondents belonged to the age group of 18-28 years. it was observed that 45 percent had Under Graduate. Further, type of working indicates that 55 percent of the respondents were Computer Professional From the present study. it was evident that $70 \%$ of respondents were Hindus. In this study $58.3 \%$ of the respondents were from nuclear family. In this study $48.3 \%$ were in the income range of Rs 2,0001-3,0000 per month, Further, the source of information on the risk factors on occurrence of coronary artery disease shows multiple responses with majority $83.3 \%$ of the respondents who got the information through medias.

The present study indicates that in the pre test Aspect wise mean knowledge score regarding the risk factor on occurrence of coronary artery disease obtained by respondents- $36.3 \%$ was obtained in the aspect of symptoms \& diagnostic procedure of coronary artery disease. However in the post test highest mean knowledge score $(97.1 \%)$ was found in the aspect of symptoms \& diagnostic procedure of coronary artery disease.

\section{REFERENCES}

1. Harvey M. Anatomical studies on the motion of the heart and blood. Textbook of Heart(Vol. I); 1970.

2. Brunner \& Sudhardh, Medical surgical nursing 10th edn, Lippincott Publication

3. Gupta R. Sarna mental (2007) fasting glucose level and cardiovascular disease risk factor in an urban population-Journal of the association of physicians of India 55.

4. Acute coronary syndrome a leading cause of mortality www.thoromosisadvisor.com/en/acs/aleading-cause of-mortality/? wT.cus campaign vendor. Harvey M. Anatomical studies on the motion of the heart and blood. Textbook of Heart (Vol. I); 1970.

5. The Health site, coronary artery disease, www.thehealth site.com/disease-conditions/ coronary

6. A study to assess the effectiveness of structured teaching programme on knowledge and attitude regarding risk factors and prevention of $\mathrm{CAD}$ among college students in selected college in tumkur.

7. Reddy SS, Prabhu GR, prevalence and risk factor of HTN in adults in an urban slum in Tirupati, Andhra Pradesh India community Medicine 2005 Jul-Sep;30(3):84-5.

8. Hujova $Z$, LesniakovaM.Anthrometric risk factors of atherosclerosis: difference between urban and rural eastslovakia children and adolescents, Bratis.2011;112:491-496.

9. Murray CJ, LopazAD.Alernative projections of mortality and disability cause 1990-220:Global burden of disease study, lancet 1997; 349,14981504.

10. WHO, the world Health report 2002, reducing risks, promoting healthy life,Geneva, WHO 2002, available from http:// www.int/whr/2002/en /whr02-en.accessed 27.1.13 